\title{
ANALISIS KEUNTUNGAN USAHA PEMBUATAN TAHU \\ PADA UD. MAKMUR SENTOSA DI KOTA MANADO
}

\author{
Naswan Indra Santho Antarani \\ Leonardus Ricky Rengkung \\ Ribka Magdalena Kumaat
}

\author{
Naskah diterima melalui Website Jurnal Ilmiah agrisosioekonomi@unsrat.ac.id \\ Rabu, 16 Oktober 2019 \\ Disetujui diterbitkan \\ : Kamis, 24 Oktober 2019
}

\begin{abstract}
This study aims to determine the benefits of tofu industry. This research was conducted at the tofu factory UD Makmur Sentosa in Kleak Urban Village, Hamlet V, Malalayang Sub-district, Manado City. The data collection method in this study used primary data collected through direct interviews with 2 business owners (husband and wife) and the entire workforce of 5 workers based on a list of questions prepared previously. Total respondents were 7 people. Secondary data obtained from the internet through Google Scholar to get articles from various scientific journals and theses from other universities related to research topics on the Profit of the business of Tofu Factory. Data collected in the form of data characteristics of business actors, raw materials, production, capital, and production costs. Tofu business UD. Makmur Sentosa is a small business that began operating in 2000 using its own capital. The amount of soybean raw material used in one month is 7,910 $\mathrm{kg}$ and produces 1,582 buckets of tofu, and produces a profit of Rp.41,811,780. So getting an $R / C$ ratio> 1 is 1.49, it means that in March 2019 the UD tofu business. Makmur Sentosa experienced profits so this business was worth the effort. ${ }^{*}$ eprm*
\end{abstract}

Keywords: profit analysis, Tofu, ratio of revenue and cost

\begin{abstract}
ABSTRAK
Penelitian ini bertujuan untuk mengetahui keuntungan usaha pembuatan tahu. Penelitian ini dilakukan di pabrik tahu UD. Makmur Sentosa di Kelurahan Kleak Lingkungan V Kecamatan Malalayang Kota Manado. Metode pengambilan data dalam penelitian ini menggunakan data primer yang dikumpulkan melalui wawancara langsung dengan 2 orang pemilik usaha (suami dan isteri) dan seluruh tenaga kerja yang berjumlah 5 orang tenaga kerja berdasarkan daftar pertanyaan yang sudah disiapkan sebelumnya. Total responden berjumlah 7 orang. Data sekunder yang diperoleh dari internet melalui google cendekia untuk mendapatkan artikel dari berbagai jurnal ilmiah dan skripsi dari perguruan tinggi lain yang berkaitan dengan topik penelitian tentang Analisis Keuntunghan Usaha Pembuatan tahu. Data yang dikumpulkan berupa data karakteristik pelaku usaha, bahan baku, produksi, modal, biaya produksi. Usaha tahu UD. Makmur Sentosa merupakan usaha kecil yang mulai beroperasi sejak tahun 2000 dengan menggunakan modal sendiri. Jumlah bahan baku kedelai yang digunakan dalam satu bulan adalah $7.910 \mathrm{~kg}$ dan menghasilkan 1.582 ember tahu, dan menghasilkan keuntungan sebesar Rp.41.811.780 Sehingga mendapatkan rasio R/C > 1 yaitu 1,49 artinya pada bulan Maret 2019 usaha tahu UD. Makmur Sentosa mengalami keuntungan sehingga usaha ini layak diusahakan. *eprm*
\end{abstract}

Kata kunci : analisis keuntungan, Tahu, rasio penerimaan dan biaya 


\section{PENDAHULUAN}

\section{Latar Belakang}

Komoditas pertanian yang ada selama ini hampir semuanya bisa diolah seperti kacang kedelai. Kedelai merupakan bahan pangan yang sangat populer di dalam kalangan masyarakat hampir setiap hari banyak orang yang mengonsumsi makanan olahan dari kedelai salah satunya tahu. Kandungan protein yang tinggi pada kedelai dan juga kandungan gizinya yang lengkap, dimana kacang kedelai merupakan bahan baku utama pembuatan tahu yang sangat dibutuhkan bagi berlangsungnya suatu proses produksi. Pendapatan usaha pengolahan tahu sangat tergantung pada harga jual produk dan biaya yang dikeluarkan untuk memproduksi tahu, semakin tinggi harga jual produk dan semakin rendah biaya maka semakin tinggi keuntungan usaha.

Usaha Tahu UD. Makmur Sentosa yang berada di Kelurahan Kleak Lingkungan IV Kecamatan Malalayang Kota Manado, berdiri pada tahun 2000 oleh Bapak Kasyanto sebagai pemilik dan mempunyai tenaga kerja sebanyak 5 orang. Setelah bertahun-tahun dengan usaha yang tidak mudah usaha tahu UD. Makmur Sentosa masih tetap bertahan dan diterima di masyarakat, dan pasar menerima tahu yang dibuat. Proses produksi tahu berlangsung setiap harinya. Didalamnya terdapat 5 karyawan yang melakukan produksi tahu setiap harinya dengan tugasnya masing-masing. Tahu yang dibuat setiap harinya tergantug pada pesanan dari konsumen.

\section{Agroindustri}

Agroindustri berasal dari dua kata agricultural dan industri yang berarti suatu industri yang menggunakan hasil pertanian sebagai bahan baku utamanya atau suatu industri yang menghasilkan suatu produk yang digunakan sebagai sarana atau input dalam usaha pertanian.

\section{Konsep Industri}

Pada dasarnya industri adalah semua kegiatan ekonomi manusia yang mengolah barang mentah atau bahan baku menjadi barang setengah jadi atau barang jadi atau menjadi barang yang lebih tinggi kegunaannya. Dalam proses produksi, faktor-faktor produksi harus digabungkan, artinya antara faktor produksi yang satu dengan yang lainnya tidak dapat berdiri sendiri tetapi dikombinasikan. Faktor- faktor yang mempengaruhi berkembangnya suatu industri meliputi modal, tenaga kerja, bahan mentah/bahan baku, transportasi, sumber energi atau bahan bakar, tenaga kerja dan pemasaran (Godan, 2006).

\section{Industri Rumah Tangga}

Dari sudut pandang Geografi Sumaatmadja (1988), menjelaskan: Industri sebagai suatu sistem, merupakan perpaduan subsistem fisis, dan subsistem manusia. Subsistem fisis yang mengandung pertumbuhan dan perkembangan industri yaitu komponenkomponen lahan, bahan mentah, atau bahan baku, sumber daya energi, iklim dengan segala macam proses alamiahnya.

\section{Kedelai}

Kedelai (Glysine $\max (L)$ Mer.) merupakan salah satu jenis kacangkacangan yang mengandung protein nabati yang tinggi, sumber lemak, vitamin, dan mineral. Apabila cukup tersedia di dalam negeri akan mampu memperbaiki gizi masyarakat melalui konsumsi kedelai segar maupun melalui konsumsi kedelai olahan seperti tahu, tempe, tauco, kecap, susu dan lain sebagainya (Kartaatmaja, 2001).

\section{Tahu Dan Pengolahan Tahu}

1. Pilih kedelai yang bersih dan besar ukurannya, kemudian cuci sampai bersih.

2. Rendam kedelai dalam air bersih selama 6 jam, Usahakan seluruh kedelai tenggelam. Dalam proses perendaman ini kedelai akan mengembang.

3. Bersihkan kembali kedelai dengan cara dicuci berkali kali. Usahakan kedelai ini sebersih mungkin untuk menghindari kedelai cepat masam.

4. Hancurkan kedelai dengan cara ditumbuk dan secara perlahan tambahkan air sedikitdemisedikit sehingga kedelainya berbentuk bubur.

5. Masak bubur kedelai dengan hati-hati pada suhu 70-80 derajat (biasanya ditandai dengan gelembung kecil yang muncul pada kedelai yang dimasak). Ingat untuk menjaga agar kedelai jangan sampai mengental.

6. Saring bubur kedelai tersebut bersama batu tahu atau asam cuka, sambil diaduk secara perlahan. Proses ini akan menghasilkan endapan tahu (gumpalan). 
7. Endapan itu kemudian siap untuk di press dan di cetak sesuai ukuran dan keinginan anda.

8. Taruh di dalam cetakan, kemudian taruh pemberat yang berfungsi untuk menekan supaya kandungan airnya benar-benar habis.

9. Keluarkan tahu dari cetakan, potong sesuai selera, dan siap dikonsumsi.

\section{Konsep Biaya}

Supriyono (2000) mengemukakan bahwa, biaya adalah harga perolehan yang digunakan dalam memperoleh penghasilan atau revenue yang akan dipakai sebagai pengurangan penghasilan. Simamora (2000) menyatakan bahwa, biaya adalah kas atau nilai kas yang digunakan untuk barang atau jasa yang diharapkan memberi manfaat saat ini atau dimasa mendatang bagi organisasi.

\section{Konsep Produksi}

Soeharno (2007), menyatakan bahwa, produksi meliputi semua aktifitas dan tidak hanya mencakup pembuatan barang-barang yang dapat dilihat. Produksi adalah suatu kegiatan untuk meningkatkan manfaat dengan cara mengkombinasikan faktor-faktor produksi kapital, tenaga kerja, teknologi. Produksi merupakan usaha meningkatkan manfaat dengan cara mengubah bentuk, memindahkan tempat, dan menyimpan.

\section{Konsep Harga}

Anoraga (2000) menyatakan bahwa, harga adalah variabel yang dapat dikendalikan dan dapat menentukan diterima tidaknya suatu produk oleh konsumen. Murah atau mahalnya harga suatu produk sangat relative sifatnya.

Fuad, dkk (2006), menyatakan bahwa harga yaitu sejumlah konpensasi baik yang berupa uang maupun barang yang dibutuhkan untuk mendapatkan sejumlah kombinasi barang dan jasa.

\section{Penerimaan}

Suratiyah (2009) menyatakan bahwa, penerimaan adalah perkalian antara jumlah produksi yang dihasilkan dengan harga jual produk. Secara matematis jumlah penerimaan dapat dituliskan sebagai berikut:

Keterangan:

$$
\mathrm{TR}=\text { Py } \mathrm{x} \text { y }
$$

$\mathrm{TR}=$ Penerimaan total $(\mathrm{Rp})$

$\mathrm{Y}=$ Jumlah produksi

Py $=$ Harga dari hasil produksi $(\mathrm{Rp})$

\section{Keuntungan}

Keuntungan usaha tahu diperoleh dengan rumus $\pi=\mathbf{T R}-\mathbf{T C}$

Keterangan:

$\pi=$ Profit (keuntungan usaha tahu)

$\mathrm{TR}=$ Total Revenue (Penerimaan pengrajin tahu)

$\mathrm{TC}=$ Total Cost (Biaya Tetap)

\section{Rumusan Masalah}

Berdasarkan latar belakang yang telah diuraikan maka rumusan masalah pada penelitian ini yaitu, bagaimana keuntungan yang didapatkan oleh usaha pembuatan tahu pada usaha tahu UD. Makmur Sentosa di Kota Manado?

\section{Tujuan penelitian}

Tujuan penelitian yaitu untuk mengetahui besarnya keuntungan usaha pembuatan tahu pada usaha tahu UD. Makmur Sentosa di Kota Manado.

\section{Manfaat Penelitian}

Manfaat yang dapat diperoleh dalam penelitian yaitu membantu memberikan informasi kepada pengrajin tentang pengembangan pengolahan tahu dimasa yang akan datang sehingga mampu memberikan keuntungan usaha yang lebih baik.

\section{METODE PENELITIAN}

\section{Tempat Dan Waktu Penelitian}

Penelitian ini berlangsung dari bulan Februari sampai dengan bulan April 2019 di Pabrik tahu UD. Makmur Sentosa Kota Manado yang dimulai pada persiapan, pengambilan data, sampai penyusunan laporan.

\section{Metode Pengumpulan Data}

Pengambilan data pada penelitian ini adalah menggunakan data primer. Data primer diperoleh melalui metode wawancara dengan menggunakan daftar pertanyaan (kuisioner) kepada pemilik usaha dan tenaga kerja, Teknik wawancara dilakukan melalui tatap muka (survei) dan tanya jawab langsung antara pengumpul data dan narasumber atau sumber data.

\section{Variabel Penelitian}

Variabel yang diamati dalam penelitian ini yaitu karakteristik usaha tahu yang meliputi: 
1. Karakteristik Responden:

- Pendidikan (SD, SMP, dan SMA)

- Lama Usaha (tahun)

- Jumlah tenaga kerja (dalam keluarga dan luar keluarga).

- Upah tenagga kerja dalam bulanan (Rp).

2. Bahan baku :

- Jumlah bahan baku : (Kg/bulan).

- Harga bahan baku : $(\mathrm{Rp} / \mathrm{Kg})$.

3. Produksi :

- Volume produksi yaitu, banyaknya jumlah produksi tahu yang dihasilkan setiap kali produksi (/hari dalam satu bulan)

4. Modal :

- Jumlah modal yang digunakan dinyatakan dalam (Rp)

5. Biaya produksi yaitu besarnya biaya yang di keluarkan pada usaha industri tahu

- Biaya penyusutan alat alat produksi (Rp/bulan)

- Biaya bahan baku $(\mathrm{Rp} / \mathrm{kg})$

- Biaya bahan penolong (Rp/bulan)

- Biaya tenaga kerja (Rp/bulan)

- Biaya bahan bakar (Rp/bulan)

\section{Analisis Data}

Analisis data yang digunakan dalam penelitian ini adalah analisis kuantitatif. Tahap analisis data yang dilakukan adalah tahap transfer dalam bentuk tabulasi, editing, dan paket perangkat lunak Microsft Exel, kemudian dilanjutkan dengan tahap intrepretasi data.

Untuk mengetahui total penerimaan dapat dihitung dengan rumus :

Keterangan:

$$
\mathrm{TR}=\mathrm{Py} \mathrm{x} y
$$

$\mathrm{TR}=$ Penerimaan total $(\mathrm{Rp})$

$\mathrm{Py}=$ Harga dari hasil produksi $(\mathrm{Rp})$

$\mathrm{Y}=$ Jumlah produksi

Keuntungan usaha tahu diperoleh dengan rumus

$$
\pi=\mathrm{TR}-\mathrm{TC}
$$

Keterangan:

$\pi=$ Profit (keuntungan usaha tahu)

$\mathrm{TR}=$ Total Revenue $($ Penerimaan pengrajin tahu $)$

$\mathrm{TC}=$ Total Cost $($ Biaya Tetap $)$

Untuk mengetahui besarnya nilai penyusutan pada setiap barang atau peralatan yang dipakai rumus adalah: $D=\frac{P-S}{\mathrm{n}}$

Keterangan:

$\mathrm{D}($ Despreciation $)=$ Biaya Penyusutan $(\mathrm{Rp} / \mathrm{bulan})$

$\mathrm{P}$ (Price) = Harga awal barang $(\mathrm{Rp})$

S $($ Salvage Value $)=$ Harga akhir barang $(\mathrm{Rp})$

$\mathrm{n}($ Life Time $)=$ Perkiraan umur ekonomis (bulan)

\section{HASIL DAN PEMBAHASAN}

\section{Gambaran Umum}

Tahu UD. Makmur Sentosa masih tergolong sebagai usaha rumah tangga. Usaha rumah tangga ini mengelolah kedelai menjadi tahu dengan jumlah tenaga kerja 5 orang. Lokasi usaha tahu ini berada di Kelurahan Kleak Lingkungan 4 Kota Manado. Sebelah Utara berbatasan dengan Kecamatan Sario, Sebelah Timur berbatasan dengan Kecamatan Pineleng, Sebelah Selatan berbatasan dengan Kecamatan Pineleng, Sebelah Barat berbatasan dengan laut Manado.

\section{Sejarah Berdirinya Perusahaan}

Tahu UD. Makmur Sentosa merupakan usaha yang bergerak dibidang yang memproduksi tahu mentah. Usaha yang terletak di Kelurahan Kleak Lingkungan IV Kecamatan Malalayang Kota Manado yang dibangun/dirintis pada tahun 2000, oleh bapak Kasyanto bersama istri Ibu Diana Lakoro. Usaha ini awalanya dibangun untuk membantu mendorong pertumbuhan perekonomian sebagai salah satu sumber pendapatan dalam rangka meningkatkan taraf hidup keluarganya, dengan menggunakan modal sendiri tanpa ada pinjaman dari orang lain. Jenis tahu yang dihasilkan oleh usaha tersebut yaitu tahu mentah yang kemudian dipasarkan di pasar Jengki, Wanea, dan beberapa warung makan yang ada di Kota Manado. Kegiatan memproduksi tahu setiap harinya tergantung pada pesanan dari permintaan pasar dan konsumen.

\section{Karakteristik Usaha Tahu \\ UD. Makmur Sentosa}

Karakteristik pengrajin tahu adalah suatu gambaran atau keadaan pengrajin tahu pada usaha pembuatan tahu yang ada di Kelurahan Kleak Lingkungan IV Karakteristik yang dimaksud dalam penelitian analisis keuntungan usaha pembuatan tahu ini meliputi umur, pendidikan, tenaga kerja, dan curahan waktu. Dalam hal ini karakteristik merupakan gambaran umum dari pengrajin tahu yang ada di di Kelurahan Kleak Lingkungan IV.

\section{Jumlah dan Persentase Responden Berdasarkan Umur Karyawan}

Kegiatan usaha yang dilakukan oleh pengrajin tahu ditentukan oleh umur yang mempengaruhi kemampuan dalam menjalankan aktifitas dan produktivitas kerja. Dari segi fisik, 
semakin tua umur responden maka akan berkurang kemampuan untuk bekerja, begitupun sebaliknya responden yang masih muda keadaan fisiknya semakin kuat dan lebih responsif terhadap usaha. Tingkat umur responden dapat dilihat pada Tabel 1.

Tabel 1. Tingkat Usia Usaha Pembuatan Tahu Pada Usaha Tahu UD. Makmur Sentosa

\begin{tabular}{lll}
\hline Umur (tahun) & Jumlah Responden & Persentase (\%) \\
\hline $20-25$ & 1 & 20 \\
$26-30$ & 3 & 60 \\
$31-35$ & 1 & 20 \\
\hline Jumlah & 5 & 100 \\
\hline
\end{tabular}

Sumber : Diolah Dari Data Primer, 2019.

\section{Jumlah dan Persentase Responden Menurut Tingkat Pendidikan}

Pendidikan merupakan salah satu aspek untuk mengetahui latar belakang kehidupan usaha tahu. Tinggi rendahnya tingkat pendidikan responden dijadikan cermin kepribadian berlaku dalam kegiatan produksi pada usaha tahu. Tinggi rendahnya pendidikan usaha tahu dapat dilihat pada Tabel 2.

Tabel 2. Tingkat Pendidikan Usaha Pembuatan Tahu Pada Usaha Tahu UD. Makmur Sentosa.

\begin{tabular}{ccc}
\hline Tingkat Pendidikan & Jumlah Responden & Persentase (\%) \\
\hline SD & 1 & 20 \\
SMP & 3 & 60 \\
SMA & 1 & 20 \\
\hline Jumlah & 5 & 100 \\
\hline
\end{tabular}

Sumber : Diolah Dari Data Primer, 2019.

\section{Jumlah dan Persentase Responden Menurut Tenaga Kerja}

Tenaga kerja yaitu orang lain yang ikut membantu usaha yang dijalankan oleh responden yang dimulai dari persiapan sampai berakhirnya produksi. Pekerjaan ini membutuhkan waktu cukup tinggi maka pemilik usaha tahu menggunakan tenaga kerja dalam melakukan produksi dan pemasaran produksi lebih jelasnya dapat dilihat pada Tabel 3.

Tabel 3. Tenaga Kerja Usaha Pembuatan Tahu Pada Usaha Tahu UD. Makmur Sentosa.

\begin{tabular}{ccc}
\hline Bagian & Jumlah Responden & Persentase (\%) \\
\hline Produksi & 4 & 80 \\
Pemasaran & 1 & 20 \\
\hline Jumlah & 5 & 100
\end{tabular}

Sumber : Diolah Dari Data Primer, 2019.

\section{Jumlah dan Persentase Responden Menurut Curahan Waktu}

Curahan waktu yaitu waktu yang dialokasikan untuk melakukan kegiatan produksi usaha tahu. Lamanya jam kerja dapat dilihat dari produktivitas yang bekerja pada usaha tahu UD.
Makmur Sentosa. Hasil wawancara dengan pemilik usaha tahu diperoleh bahwa waktu produksi rata-rata $12 \mathrm{jam} / \mathrm{hari}$. Untuk lebih jelasnya dapat dilihat paad Tabel 4.

Tabel 4. Curahan Waktu Usaha Pembuatan Tahu Pada UD. Makmur Sentosa.

\begin{tabular}{ccc}
\hline Curahan Waktu (Jam) & Jumlah Responden & Persentase (\%) \\
\hline 12 & 2 & 28,57 \\
10 & 2 & 28,57 \\
7 & 3 & 42,86 \\
\hline Jumlah & 7 & 100 \\
\hline
\end{tabular}

Sumber : Diolah Dari Data Primer, 2019.

\section{Proses Produksi}

Proses produksi adalah kegiatan usaha tahu untuk memproses dan mengubah bahan baku kedelai menjadi produk tahu melalui penggunaan tenaga kerja dan fasilitas produksi lainya. Proses pembuatan tahu cukup mudah asalkan bahan baku dan peralatan yang dibutuhkan sudah tersedia.

Berikut ini alat dan bahan serta proses pembuatan tahu:

\section{Peralatan}

Dalam proses produksi pada usaha tahu UD. Makmur Sentosa tentunya memerlukan peralatan tertentu berikut ini adalah peralatan yang diigunakan dalam proses produksi tahu dapat dilihat pada Tabel 5 .

\begin{tabular}{|c|c|c|c|}
\hline No & Uraian & Jumlah (unit) & Harga beli (Rp) \\
\hline 1 & Mesin Penggiling & 1 & 10.000 .000 \\
\hline 2 & Ember & 100 & 3.000 .000 \\
\hline 3 & Cetakan & 12 & 1.200 .000 \\
\hline 4 & Kain Saring & 6 & 84.000 \\
\hline 5 & $\begin{array}{l}\text { Kain penutup } \\
\text { cetakan }\end{array}$ & 6 & 84.000 \\
\hline 6 & Mesin Air (Sanyo) & 1 & 1.500 .000 \\
\hline 7 & Pisau & 1 & 5000 \\
\hline 8 & Selang Air & 1 & 150.000 \\
\hline 9 & Belanga Masak & 1 & 3.500 .000 \\
\hline 10 & Belanga (sendok) & 1 & 50.000 \\
\hline 11 & Tong Air & 1 & 750.000 \\
\hline 12 & Sepatu Boots & 6 & 720.000 \\
\hline 13 & Kaos Kaki & 12 & 180.000 \\
\hline & Jumlah & & 21.223 .000 \\
\hline
\end{tabular}

\section{Proses pembuatan produk tahu}

Berikut ini adalah alur proses produksi tahu "UD. Makmur Sentosa dapat dilihat pada gambar 1.

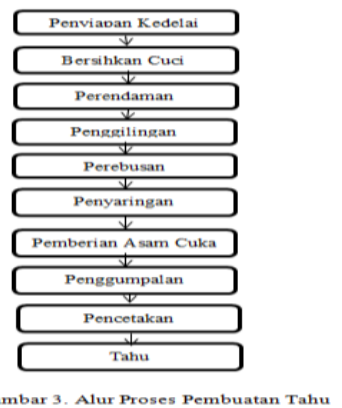




\section{Penggunaan Bahan Baku}

\section{Bahan Baku}

Bahan baku utama yang digunakan dalam pembuatan produk tahu yaitu kedelai. Pemesanan dilakukan setiap hari dengan jumlah bahan baku kedelai setiap harinya berbeda-beda tergantung pada banyaknya pesanan. Bahan baku kedelai dibeli dengan harga $\mathrm{Rp} 8.500 / \mathrm{kg}$ sebanyak $7910 \mathrm{~kg}$ pada bulan Maret. Biaya yang digunakan untuk bahan baku selama bulan Maret 2019 Rp. 67.235.000, untuk proses produksi ini dilakukan setiap hari, waktu pembuatan produk tahu untuk setiap hari produksinya memerlukan waktu 12 jam.

\section{Penggunaan Tenaga Kerja}

Pengunaan tenaga kerja dalam usaha ini hanya memperkerjakan lima orang tenaga kerja. Dari hasil penelitian yang didapat bahwa pengantaran produk membutuhkan biaya bahan bakar Rp.1.350.000 pada bulan Maret, dan untuk tenaga kerja empat orang pada bagian produksi mendapatkan upah setiap tenaga kerja Rp.2.000.000, dan untuk sopir Rp. 1.500.000/bulan.

\section{Modal}

Modal awal pada usaha Tahu UD. Makmur Sentosa merupakan modal dari pemilik sendiri atau modal sendiri dan tidak mendapatkan bantuan dari pihak lain. Dari modal yang sudah ada pemilik usaha tahu menggunakanya untuk pembelian perlengkapan yang dibutuhkan seperti peralatan, bahan yang akan digunakan dalam proses produksi untuk menjalankan usaha ini. Berikut ini modal tetap pada usaha tahu UD. Makmur Sentosa" dapat dilihat pada Tabel 6 .

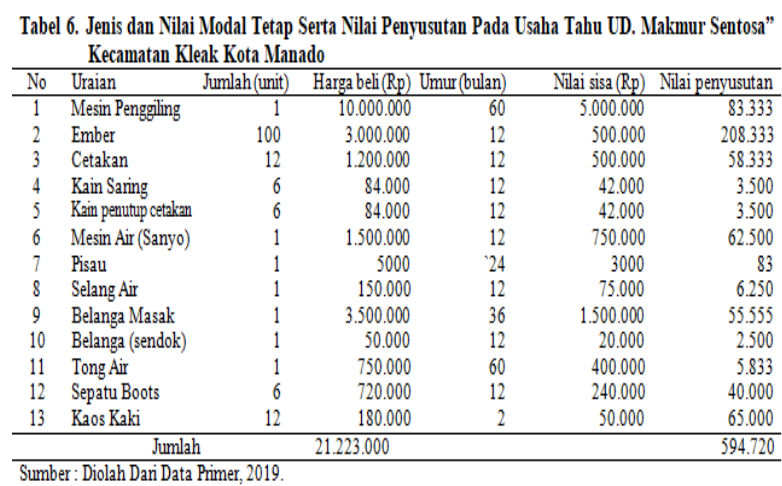

\section{Biaya, Penerimaan dan Keuntungan}

Dalam kegiatan produksi dapat dinilai hasil yang diperoleh dari biaya yang dikeluarkan selama produksi berlangsung. Adapun data yang dianalisis adalah biaya produksi yang terjadi dalam satu kali produksi selama bulan Maret 2019.

\section{Biaya Tetap}

Biaya tetap adalah biaya yang tidak tergantung pada banyak sedikitnya produk yang dihasilkan oleh usaha tersebut, pengeluaran ini berkaitan dengan waktu. Dalam usaha tahu UD. Makmur Sentosa yang termaksud dalam biaya tetap adalah biaya penyusutan alat.

Biaya-biaya tersebut menyangkut semua pengeluaran untuk memperoleh produk tahu dimana produk yang dikeluarkan tersebut diharapkan dapat memberikan keuntungan bagi usaha tahu UD. Makmur Sentosa Perhitungan biaya tetap dapat dilihat pada Tabel 7.

Tabel 7. Jenis Alat Dan Jumlah Biaya Tetap Dari Penyusutan Alat Selama Bulan Maret 2019

\begin{tabular}{|c|c|c|c|}
\hline No & Uraian & $\begin{array}{l}\text { Lama Pemakaian } \\
\text { (bulan) }\end{array}$ & $\begin{array}{c}\text { Nilai } \\
\text { penyusutan }\end{array}$ \\
\hline 1 & $\begin{array}{l}\text { Mesin } \\
\text { Penggiling }\end{array}$ & 60 & 83.333 \\
\hline 2 & Ember & 12 & 208.333 \\
\hline 3 & Cetakan & 12 & 58.333 \\
\hline 4 & Kain Saring & 12 & 3.500 \\
\hline 5 & $\begin{array}{l}\text { Kain penutup } \\
\text { cetakan }\end{array}$ & 12 & 3.500 \\
\hline 6 & $\begin{array}{l}\text { Mesin Air } \\
\text { (Sanyo) }\end{array}$ & 12 & 62.500 \\
\hline 7 & Pisau & 24 & 83 \\
\hline 8 & Selang Air & 12 & 6.250 \\
\hline 9 & Belanga Masak & 36 & 55.555 \\
\hline 10 & $\begin{array}{l}\text { Belanga } \\
\text { (sendok) }\end{array}$ & 12 & 2.500 \\
\hline 11 & Tong Air & 60 & 5.833 \\
\hline 12 & Sepatu Boots & 12 & 40.000 \\
\hline 13 & Kaos Kaki & 2 & 65.000 \\
\hline & Jumlah & & 594.720 \\
\hline
\end{tabular}

\section{Biaya Variabel}

Biaya variabel adalah biaya yang berubah secara proposional dengan aktifitas bisnis, atau biaya yang dikeluarkan untuk faktor produksi yang memiliki sifat berubah-ubah dan akan mempengaruhi besarnya volume produksi atau yang direncanakan. Biaya variabel pada penelitian ini adalah biaya bahan baku, kayu bakar, bahan penolong, bahan bakar kendaraan, tenaga kerja, dan biaya listrik yang dihitung selama bulan Maret 2019. 
a. Biaya Bahan Baku

Bahan baku yang digunakan pada usaha tahu UD. Makmur Sentosa adalah kedelai. Dari hasil penelitian selama bulan Maret 2019 usaha tahu menggunakan bahan baku kedelai sebanyak $7.910 \mathrm{Kg}$ dengan harga per kilonya Rp. 8.500. Sehingga pengeluaran untuk bahan baku kedelai pada bulan maret sebesar Rp. 67.235.000.

b. Biaya Bahan Bakar

Bahan Bakar yang digunakan pada usaha tahu UD. Makmur Sentosa adalah tempurung pala. Dari hasil pengambilan data pada bulan maret 2019 usaha tahu menggunakan bahan bakar tempurung pala sebanyak 120 karung dengan harga per karungnya Rp. 50.000. Sehingga pengeluaran yang dikeluarkan untuk membeli bahan bakar pada bulan maret berjumlah sebesar Rp. 6.000.000.

c. Biaya Bahan Penolong

Bahan penolong langsung merupakan bahan yang digunakan dalam memproduksi tahu. Bahan penolong yang digunakan pada usaha tahu UD. Makmur Sentosa adalah asam cuka. Asam cuka yang digunakan selama bulan maret sebanyak 2 botol dengan harga per botol Rp.10.000. sehingga pengeluaran pada bahan penolong dibulan Maret 2019 adalah sebesar Rp. 20.000.

d. Biaya Bahan Bakar Kendaraan

bahan bakar yang digunakan adalah premium/bensin sebanyak 186 litre dengan harga per litre Rp. 6.450. sehingga pengeluaran pada bulan maret sebanyak Rp. 1.200.000.

e. Biaya Tenaga Kerja

Jumlah tenaga kerja yang digunakan pada usaha tahu adalah sebanyak 5 orang. 4 orang bekerja pada bagian produksi, dan 1 orang bekerja pada bagian pemasaran (Sopir), pada bagian produksi menerima upah tiap bulan Rp.2.000.000. Sedangkan pada bagian pemasaran mendapatkan upah per bulan Rp. 1.500.000. Sehingga total pengeluaran untuk biaya tenaga kerja pada bulan maret adalah sebanyak Rp. 9.500.000.

f. Biaya Listrik

Dari hasil penelitian yang dilakukan pada usaha tahu UD. Makmur Sentosa, bahwa biaya listrik pada bulan Maret 2019 adalah sebesar Rp. 397.000. Biaya listrik ini dibagi menjadi dua yakni biaya listrik yang dipakai untuk proses produksi pada usaha tahu dan biaya listrik untuk kebutuhan rumah tangga, dengan besar biaya yang dibagi jumlahnya sama besar yaitu masing-masing Rp. 198.500.

\section{Biaya Total}

Total biaya pada usaha tahu UD. Makmur Sentosa selama bulan Maret dapat dilihat pada Tabel 8 .

Tabel 8. Total Biaya Usaha Tahu UD. Makmur Sentosa selama bulan Maret 2019

\begin{tabular}{clr}
\hline No & Uraian Biaya & Nilai Rp \\
\hline 1 & Biaya Tetap & \\
& Biaya Penyusutan Alat & 594.720 \\
& Jumlah Biaya Tetap & 594.720 \\
2 & Biaya Variabel & 67.235 .000 \\
& Bahan Baku & \\
& Bahan bakar (Tempurung & 6.000 .000 \\
& Pala) & \\
Bahan Penolong (Asam & 20.000 \\
Cuka) & 1.200 .000 \\
& Bahan Bakar Kendaraan & 9.500 .000 \\
& Tenaga Kerja & 198.500 \\
& Listrik & 84.153 .500 \\
\hline & Jumlah Biaya Variabel & 84.748 .220 \\
\hline & Total Biaya &
\end{tabular}

\section{Penerimaan (Revenue)}

Penerimaan yang diterima oleh usaha tahu dihitung selama satu periode yaitu satu bulan. Perhitungan penerimaan dilakukan dengan cara menghitung produksi setiap minggunya.

Tabel 10. Jumlah Produksi Bulan Maret 2019 Usaha Tahu UD. Makmur Sentosa di Kota Manado

\begin{tabular}{cccrc}
\hline Tanggal & $\begin{array}{c}\text { Bahan Baku } \\
(\mathrm{kg})\end{array}$ & $\begin{array}{c}\text { Hasil Produksi } \\
(\text { Ember })\end{array}$ & $\begin{array}{c}\text { Harga Jual } \\
(\mathrm{Rp} / \text { Ember })\end{array}$ & $\begin{array}{c}\text { Penerimaan } \\
(\mathrm{Rp})\end{array}$ \\
\hline $01-07$ & 1750 & 350 & 80.000 & 28.000 .000 \\
$08-14$ & 1785 & 357 & 80.000 & 28.560 .000 \\
$15-21$ & 1770 & 354 & 80.000 & 28.320 .000 \\
$22-31$ & 2605 & 521 & 80.000 & 41.680 .000 \\
\hline Jumlah & 7.910 & 1.582 & 80.000 & 126.560 .000 \\
\hline Sumber $:$ Diol & & & &
\end{tabular}

\section{Keuntungan}

Keuntungan yang diterima oleh usaha tahu tentunya telah dikurangi dengan semua biaya yang digunakan pada saat proses produksi tahu yang dihasilkan. Untuk menghitung keuntungan yang diperoleh usaha tahu UD. Makmur Sentosa pada bulan maret dapat dihitung menggunakan rumus keuntungan yaitu:

$$
\pi=\mathrm{TR}-\mathrm{TC}
$$

Keterangan :

$\pi=$ Profit (keuntungan Pengrajin tahu)

$\mathrm{TR}=$ Total Revenue (Penerimaan pengrajin tahu)

$\mathrm{TC}=$ Total Cost (Biaya)

$\pi=126.560 .000-84.748 .220$

$\pi=\operatorname{Rp} 41.811 .780$ 


\section{KESIMPULAN DAN SARAN}

\section{Kesimpulan}

Bardasarkan hasil penelitian Analisis Keuntungan Usaha Pembuatan Tahu Pada UD. Makmur Sentosa di Kelurahan Kleak Lingkungan IV Kecamatan Malalayang Kota Manado dapat diambil kesimpulan bahwa:

1. Usaha Tahu UD. Makmur Sentosa memproduksi tahu pada bulan maret mengeluarkan biaya produksi sebesar Rp. 84.748.220.

2. Pendapatan atau penerimaan oleh usaha Tahu UD. Makmur Sentosa sebesar Rp. 126.560.000.

3. Keuntungan yang diperoleh Usaha Tahu UD. Makmur Sentosa adalah sebesar Rp. 41.811.780 pada bulan maret 2019 .

\section{Saran}

Dari hasil penelitian yang diperoleh ada beberapa saran yang dapat disampaikan:

1. Usaha pembuatan tahu hendaknya lebih memperhatikan curahan waktu dalam melakukan proses produksi, karena dari hasil penelitian bahwa curahan waktu pada usaha tahu tersebut tidak berjalan sesuai yang ditetapkan oleh usaha tahu (jika pesanan meningkat maka seluruh tenagga kerja akan bekerja selama 12 jam yaitu mulai dari jam 03.00 sampai jam 15.00 dalam melakukan proses produksi)

2. Usaha pembuatan tahu hendaknya lebih memperhatikan banyaknya peminat (konsumen) tahu di Kota Manado karena dari hasil penelitian bahwa para konsumen atau pembeli yang datang untuk membeli tahu, tahunya sudah habis terjual untuk itu diharapkan kepada usaha tahu dalam setiap memproduksi tahu untuk menambah volume produksi olahan tahu di setiap kali produksi.

3. Kepada usaha Tahu UD. Makmur Sentosa diharapkan tetap mempertahankan keuntungan yang diperoleh.

\section{DAFTAR PUSTAKA}

Anoraga, Pandji. 2000. Manajemen Bisnis. Jakarta: Rineka Cipta.

Fuad, M, dkk. 2006. Pengantar Bisnis. Cetakan Kelima. Jakarta : PT Gramedia.

Kartaatmaja, S. 2001. Penanganan Pscapanen dan Pengolahan Biji Kedelai. Departmen Pertanian Badan Penelitian dan Pengembangan Pengkajian Teknologi Pertanian Jawa Tengah. Pustaka Utama. 